\title{
MONITORING OF FRESHWATER TOXINS IN EUROPEAN ENVIRONMENTAL WATERS BY USING NOVEL MULTI-DETECTION METHODS
}

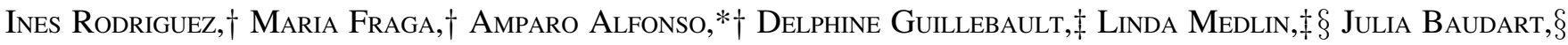 \\ Pauline Jacob, $\|$ Karim Helmi, $\|$ Thomas Meyer,\# Ulrich Breitenbach,\# Nicholas M. Holden, $† \dagger$ Bas Boots, $† \dagger$ \\ Roberto Spurio, $\ddagger$ Lucia Cimarelli, $\ddagger$ Laura Mancini,§§ Stefania Marcheggiani,§§ Meric Albay, $\mid\|\|$ \\ Reyhan AkCaalan, \|\||| Latife KöKer, \|\| $\mid$ and Luis M. Botana*† \\ $\dagger$ Department of Pharmacology, Faculty of Veterinary, Universidade de Santiago de Compostela, Lugo, Spain \\ $\ddagger$ Microbia Environnement, Observatoire Océanologique, France \\ $\S$ Laboratoire de Biodiversité et Biotechnologies Microbiennes, Centre National de la Recherché Scientifique, Observatoire Océanologique Sorbonne \\ Universités, Université Pierre et Marie Curie, Paris, France \\ $\|$ Centre de Recherche de Saint Maurice, Veolia Recherche et Innovation Immeuble le Dufy, St. Maurice, France \\ \#MariLim Aquatic Research, Schoenkirchen, Germany \\ ††School of Biosystems Engineering, Agriculture and Food Science, University College Dublin, Belfield, Dublin, Ireland \\ $\ddagger \ddagger$ Laboratory of Genetics, School of Biosciences and Veterinary Medicine, University of Camerino, Camerino, Italy \\ $\S \S$ Environmental, Quality and Fishfarm Unit, Environment \& Primary Prevention Department, Istituto Superiore di Sanità, Rome, Italy \\ |||Fisheries Faculty, Istanbul University, Istanbul, Turkey
}

(Submitted 7 March 2016; Returned for Revision 4 June 2016; Accepted 7 August 2016)

\begin{abstract}
Monitoring the quality of freshwater is an important issue for public health. In the context of the European project $\mu$ Aqua, 150 samples were collected from several waters in France, Germany, Ireland, Italy, and Turkey for 2 yr. These samples were analyzed using 2 multitoxin detection methods previously developed: a microsphere-based method coupled to flow-cytometry, and an ultra-performance liquid chromatography-tandem mass spectrometry (UPLC-MS/MS) method. The presence of microcystins, nodularin, domoic acid, cylindrospermopsin, and several analogues of anatoxin-a (ATX-a) was monitored. No traces of cylindrospermopsin or domoic acid were found in any of the environmental samples. Microcystin-LR and microcystin-RR were detected in 2 samples from Turkey and Germany. In the case of ATX-a derivatives, $75 \%$ of samples contained mainly $\mathrm{H}_{2}$-ATX-a and small amounts of $\mathrm{H}_{2}$-homoanatoxin-a, whereas ATXa and homoanatoxin-a were found in only 1 sample. These results confirm the presence and wide distribution of dihydro derivatives of ATX-a toxins in European freshwaters. Environ Toxicol Chem 2017;36:645-654. (C) 2016 SETAC
\end{abstract}

Keywords: Freshwater toxins Microcystins Anatoxin-a Homo-anatoxin-a Dihydro-anatoxin-a

\section{INTRODUCTION}

Aquatic ecosystems represent important natural resources essential for supplying drinking water and constitute the economic base for fisheries and industrial, agricultural, and recreational activities. Increased levels of 1 or more limiting nutrients can enhance the biological production of the ecosystem, resulting in a dangerous status known as eutrophication. The appearance of this phenomenon has increased in relation to human activities, although it has occurred naturally for centuries [1]. Eutrophication can result in excessive growth of harmful microorganisms, such as some cyanobacteria or even diatoms, posing a threat to human health when toxic species proliferate. In freshwater, cyanobacteria, or blue-green algae, are the most common organisms present during microalgal proliferations. The excessive growth episodes are known as cyanobacterial harmful algal blooms. Increasing numbers of these microorganisms produce toxic metabolites called cyanotoxins. Three groups of compounds with different effects and structures are included within the term "cyanotoxins": hepatotoxins, as microcystins (MCs), nodularins (NODs), and cylindrospermopsins (CYNs); neurotoxins, as anatoxin-a (ATX-a) and analogues, saxitotins, and B-N-methylamino-L-

\footnotetext{
* Address correspondence to amparo.alfonso@usc.es or Luis.Botana@usc.es Published online 8 July 2016 in Wiley Online Library (wileyonlinelibrary.com).

DOI: $10.1002 /$ etc. 3577
}

alanine; and dermatotoxins, as aplysiatoins and lyngbyatoxins [2]. These compounds can produce severe effects and have been associated with numerous animal and human poisonings [3]. As consequence, cyanotoxins are considered as an environmental and public health concern. The World Health Organization has established a provisional upper limit of $1 \mu \mathrm{g}$ microcystin-LR (MC-LR)/L drinking water [4]; however, other microalgal toxins are becoming increasingly recognized as potential risks to both human and animal health, resulting in their inclusion in legal regulations regarding the safety of waters of several countries $[2,5,6]$. Recently, US Environmental Protection Agency (USEPA) recommended limits below $1.6 \mu \mathrm{g} / \mathrm{L}$ and $0.3 \mu \mathrm{g} / \mathrm{L}$ of MC-LR for adults and children, respectively, and a limit of $3 \mu \mathrm{g} / \mathrm{L}$ of CYN [7].

Microcystins have been isolated from microorganisms such as Microcystis, Anabaena, Oscillatoria, Planktothrix, Chroococcus, Nostoc, and Anabaenopsis [8]. Their cyclic heptapeptide scaffold (D-Ala-X-D-MeAsp-Z-Adda-D-GluMdha) has approximately 90 structural variants though aminoacidic modifications (as representative examples, the modifications for 2 common analogs, MC-RR and MC-YR, are shown in the Figure 1). Once ingested, MCs are concentrated in hepatic tissues, where they bind to the catalytic subunit of protein phosphatases, triggering hepatotoxicity. It has been suggested that this biological target is also involved in tumor development $[2,9,10]$. The NODs, mostly synthesized by the cyanobacteria Nodularia spumigena, are chemically similar to 


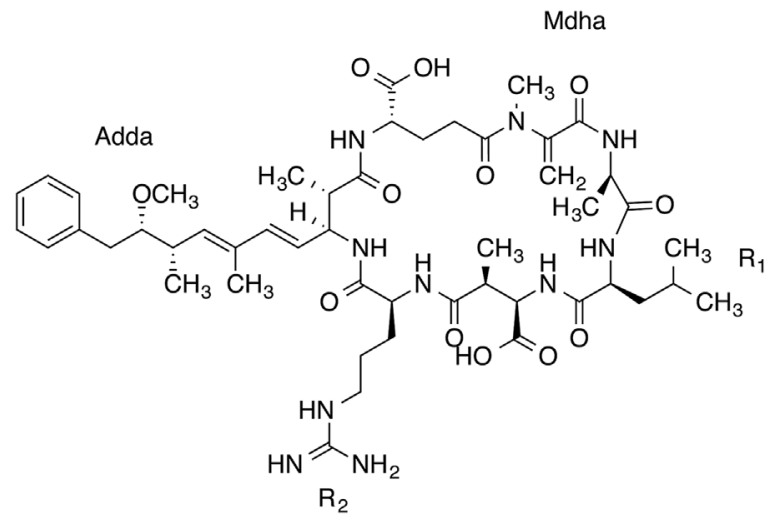

Microcystin-LR<smiles>C[C@@H]1C(c2cc(=O)[nH]c(=O)[nH]2)NC[C@@H]2NC(=O)N[C@H](CO)C[C@@H]2C[C@@H]1OS(=O)(=O)O</smiles>

Cylindrospermopsin

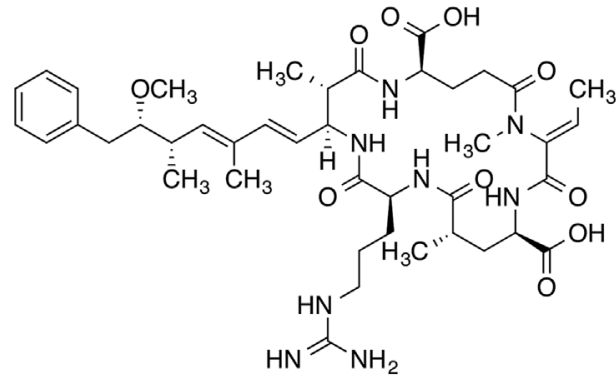

Nodularin

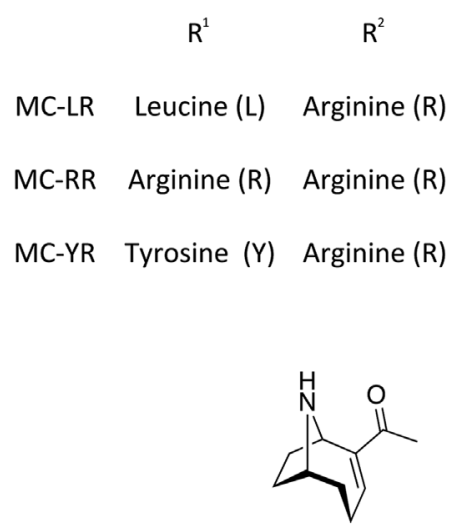

Anatoxin-a

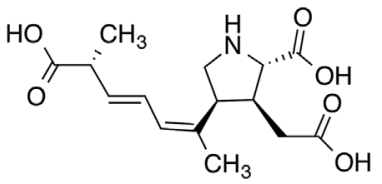

Domoic acid

Figure 1. Structures of the representative toxins analyzed in the present study: microcystin-LR, cylindrospermopsin, anatoxin-a, domoic acid, and nodularin. $\mathrm{MC}=$ microcystin.

MCs because they are also cyclic pentapeptides (Adda-D-GluMeDhb-D-MeAsp-L-Arg); however, fewer than 10 analogs have been described to date. The main mechanism of action for NODs also involves protein phosphates and can lead to high tumorogenic activity [11,12]. Different CYNs producing microorganisms have been identified, including Cylindrospermopsis, Aphanizomenon, Umezakia, Raphidiopsis, Anabaena, and Lygnbya [13]. The CYN is a tricyclic alkaloid, and modifications of this structure have resulted in an epimer and an analog (7-deoxy-CYN) [14,15]. Hepatotoxicity, potential carcinogenicity, and protein synthesis inhibition have been associated with CYN [9,16,17]. Several species of Anabaena, Aphanizomenon, Oscillatoria, Phormidium, Cylindrospermum, Raphidiopsis, and Planktothrix have been described as ATX-a toxins producers $[18,19]$. The main representatives compounds of this group of toxins are the alkaloid ATX-a and its analog homoanatoxin-a (homoATX-a), 2 potent agonists of nicotinic acetylcholine receptors (nAChR) [20-23]. The chemical instability of both toxins leads to the occurrence of epoxy and dihydro products [24,25], although some of these compounds can occur naturally $[18,26]$. In addition to the above toxins, the present study also analyzed the group of amnesic shellfish toxins (ASTs) because the production of ASTs by diatoms belonging the genera Pseudo-nitzschia and Nitzschia has been reported in brackish waters [27]. The ASTs include domoic acid (DA) and its 9 isomers (isodomoic-A to iso-domoic-H and epi-domoic acid), which bind to and activate kainate receptors, causing neurological symptoms such as amnesia as well as gastrointestinal effects [28,29]. Therefore, microalgal toxins represent a global sanitary threat, as their occurrence has been reported worldwide. In this sense, a recent study established a correlation between the presence of cyanobacteria and MC-LR and gastrointestinal symptoms, which underscores the importance of the control of freshwater toxins to protect human and wildlife health [30].

Several methods for detecting cyanotoxins in the environment have been developed [31], including the use of microspheres coupled to flow-cytometry system [32] and ultraperformance liquid chromatography-tandem mass spectrometry, UPLC-MS/MS [33]. The flow-cytometry technology coupled to microspheres with different spectral properties and surface carboxyl groups allows to the covalent immobilization of ligands. Each type of microsphere is specific for an analyte (i.e., toxin), which recognizes through the specific ligand covalently attached on its surface. The flow cytometry system separates individual microspheres with red and green lasers and allows the quantification of attached compound. Multiplexing is provided by the simultaneous incubation of a sample with multiple types of analyte-specific microspheres. This technology has been widely employed in clinical and research fields [34]. The UPLC-MS/MS method is a fast analytical technology used to detect and quantify cyanobacterial toxins. For toxin quantification, the mass spectrometric methods are based on detection in multiple-reaction monitoring mode. In this way, high selectivity and sensitivity are possible because at least 2 product ions by compound are identified. An efficient detection system can be done using first a screening method 
Table 1. Details of source, dates, and types of water from samples during the 2-yr monitoring campaign

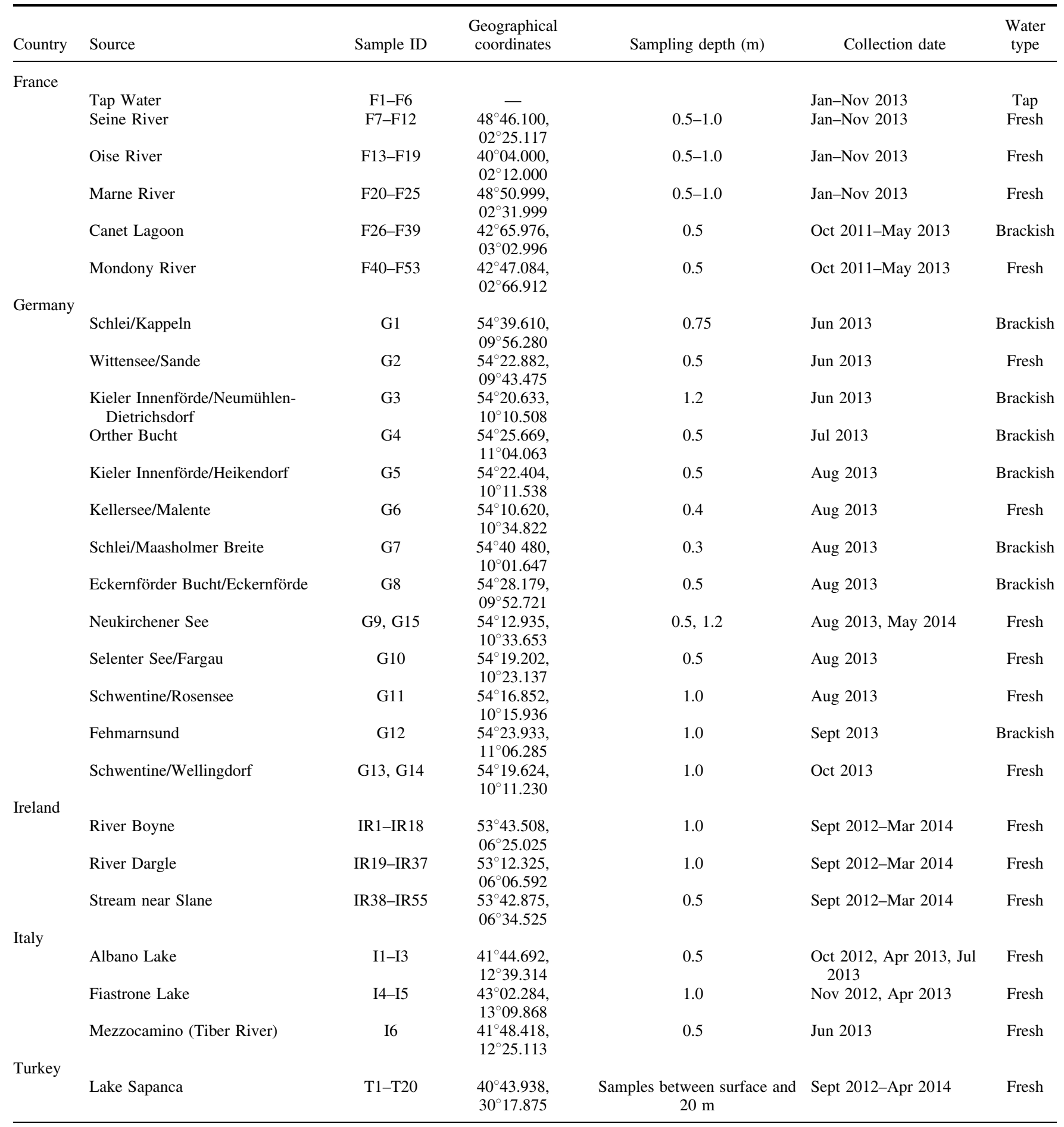

based on the use of the flow-cytometry technology and toxinspecific microspheres, which would indicate the presence/ absence of toxins, followed by an analytical method, such as UPLC-MS/MS, allowing quantification of the toxins and identification of different analogues. In the present study, these 2 technologies were applied to screen 150 samples collected during a 2-yr monitoring campaign as part of the European project (Universal Microarrays for the Evaluation of FreshWater Quality Based on Detection of Pathogens and Their Toxins ( $\mu$ Aqua).

\section{MATERIAL AND METHODS}

Materials

Certified reference standard material of DA was obtained from CIFGA. Domoic acid for immobilization was purchased from Merck Millipore and CIFGA. Anatoxin-a, CYN, MC-LR, MC-YR, and MC-RR were obtained from ENZO. Biotin- $\alpha-$ bungarotoxin was from Molecular Probes. Analytical standard of MC-LR, MC-YR, MC-RR, N-hydroxysuccinimide, sodium tetraborate decahydrate, jeffamine $\left(2,2^{\prime}\right.$-[ethylenedioxy] 

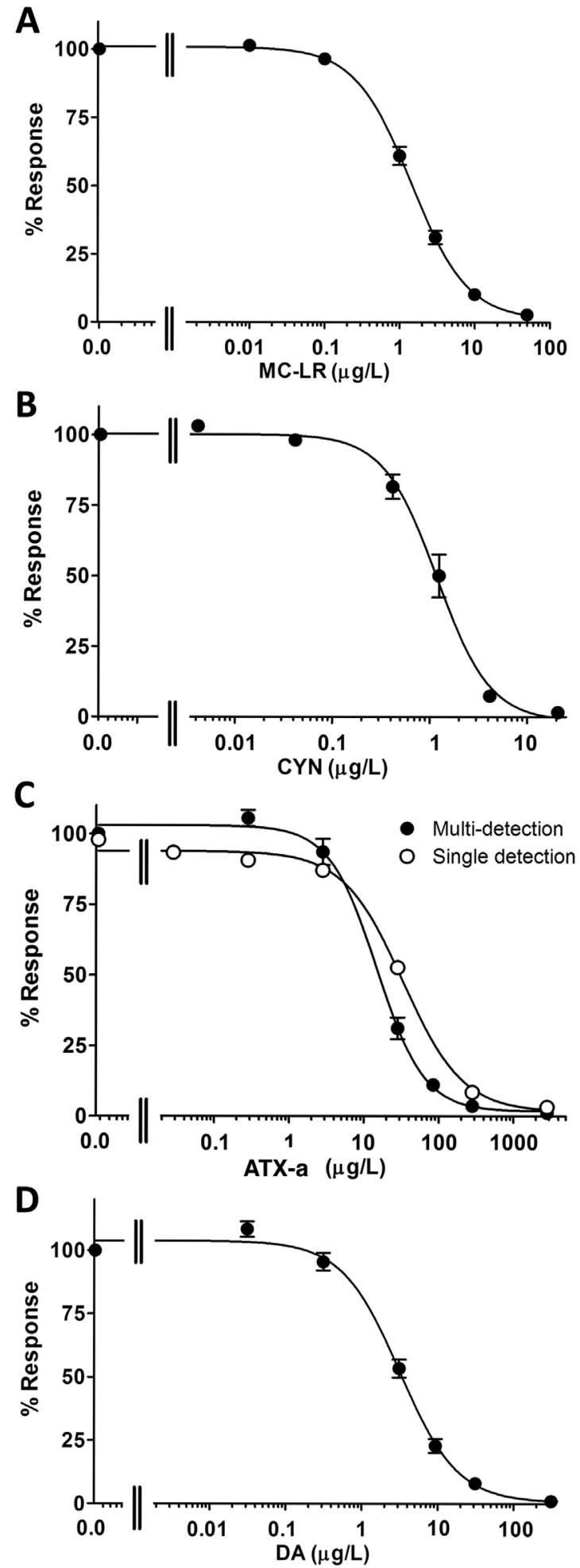

Figure 2. Microsphere-based detection method for (A) mycrocystin-LR (MC-LR), (B) cylindrospermopsin (CYN), (C) anatoxin-a (ATX-a), and (D) domoic acid (DA). Calibration curves for MC-LR, CYN, ATX-a, and DA were performed simultaneously in buffer solution (MC-LR, CYN, DA: mean \pm standard error, $n=7$; ATX-a: mean \pm SEM, $n=5$ ).

bis[ethylamine]), ethylenediamine, boric acid, sodium phosphate monobasic, ethanolamine, and Tween-20 were purchased from Sigma-Aldrich. The 1-ethyl-3-(3-dimethylaminopropyl) carbodiimide hydrochloride was purchased from Pierce. The anti-MC-LR (MC-LR-Ab), anti-CYN (CYN-Ab), and anti-DA
(DA-Ab) antibodies were obtained as previously described [35-37]. The acetylcholine binding protein from Lymnaea stagnalis (Ls-AChBP) was purified and characterized as previously described [38,39]. Phycoerythrin goat anti-mouse Ig (PE-Ab) was purchased from Invitrogen, phycoLink streptavidin-R phycoerythrin (PE-SA) from Prozyme, and sodium azide from Fluka. Carboxylated microspheres (LC10019-01, LC10027-01, LC10050-01, and LC10054-01) were from Luminex Corporation. Luminex sheath fluid, multiscreen 96-well filter plates, a 33-mm Millex filter with $0.45-\mu \mathrm{m}$ pore size, and Ultrafree-MC (Durapore membrane) and Ultrafree-CL centrifugal filters (Low binding Durapore PVDF membrane) were purchased from Millipore. Hemoflow cartridges HF80S were from Fresenius Medical Care.

Formaldehyde (37\%), dimethyl sulfoxide, sodium acetate anhydrous, disodium hydrogen phosphate anhydrous, and sodium chloride were obtained from reagent grade commercial sources (Sigma-Aldrich). Acetonitrile and methanol were supplied by Panreac. All solvents employed in the present study were HPLC grade or analytical grade, and the water was distilled and passed through a water purification system (MilliQ; Millipore). Phosphate-buffered saline solution (PBS) was made from $130 \mathrm{mM} \mathrm{NaCl}, 1.5 \mathrm{mM} \mathrm{NaH}_{2} \mathrm{PO}_{4}, 8.5 \mathrm{mM}$ $\mathrm{Na}_{2} \mathrm{HPO}_{4}(\mathrm{pH}$ 7.4). The PBS-BT solution was made as PBS supplemented with $0.1 \% \mathrm{w} / \mathrm{v}$ BSA and $0.1 \%$ v/v Tween-20.

\section{Extraction of water samples}

Water samples were collected from different countries in Europe (France, Germany, Ireland, Italy, and Turkey; see Table 1) during 2012, 2013, and 2014 as part of the $\mu$ AQUA monitoring campaign. The selection of each sample collection station was done as representative of the country within the project scope, and it was identified according to geographical coordinates.

From each station, samples of $50 \mathrm{~L}$ of water were collected and concentrated to $1 \mathrm{~L}$ using a hemoflow cartridge $(60 \mathrm{Da}$ exclusion size), following manufacture specifications (Fresenius Care) [40]. Aliquots of $40 \mathrm{~mL}$ of the concentrate were separately frozen at $-20{ }^{\circ} \mathrm{C}$ and sent to the laboratory of the Universidade de Santiago de Compostela in dry ice. On arrival, the samples were thawed and then sonicated 3 cycles of $30 \mathrm{~s}$ prior to use. Then the samples were centrifuged, and aliquots of $10 \mathrm{~mL}$ were separated. These aliquots were vacuum dried and dissolved in methanol $(1 \mathrm{~mL})$ and centrifuged $3700 \mathrm{rpm}$ for $10 \mathrm{~min}$ at room temperature. The supernatants were filtered through $0.45-\mu \mathrm{m}$ filters (Millipore), vacuum dried, and redissolved in water or PBS-BT for subsequent analyses. Concentration steps to detect small amounts of toxins were added when necessary. The final concentration of toxins was always expressed per liter of water.

Microsphere-based multidetection assay for MC-LR, CYN, ATX-a, and $D A$

In this method, MC-LR, CYN, DA, and Ls-AChBP were covalently attached to the carboxylated surface of 4 different types of microsphere (LC10050-01, LC10019-01, LC10054-01, and LC10027-01, respectively) and validated as previously described [32,41,42]. The detection method was designed and validated to include 4 simultaneous competition assays to be performed in the same well [32]. Briefly, during the first step, $60 \mu \mathrm{L}$ of sample or calibration solution (containing a mixture of MC-LR, CYN, ATX-a, and DA) were incubated with $60 \mu \mathrm{L}$ of the specific antibodies (MC-LR-Ab, CYN-Ab, and DA-Ab) and $2 \times 10^{3}$ of prewashed Ls-AChBP-coated microspheres in a 
microtiter plate. After $1 \mathrm{~h}$ of incubation, $100 \mu \mathrm{L}$ of this mixture were transferred to a second microtiter filter plate containing washed toxin-coated microspheres $\left(2 \times 10^{3}\right.$ MC-LR-microspheres, $2 \times 10^{3}$ CYN-microspheres, $2 \times 10^{3}$ DA-microspheres). After $1 \mathrm{~h}$ of incubation, $100 \mu \mathrm{L}$ of $\alpha$-BTX were added, and the mixture was incubated for $30 \mathrm{~min}$ and then washed. Finally, $100 \mu \mathrm{L}$ of PE-labeled molecules (PE-Ab and PE-SA) were added, and the mixture was incubated for $1 \mathrm{~h}$. After a washing step, the microspheres were suspended in $100 \mu \mathrm{L}$ of PBS-BT and analyzed on a Luminex 200 analyzer (LuminexCorp). Microspheres were classified with a 635-nm wavelength laser, and PE fluorescence was quantified after excitation with a 532-nm wavelength laser. The acquisition volume was $75 \mu \mathrm{L}$, and the minimum number of bead counts was 100. All experiments were performed in duplicate. The incubations were performed at room temperature, and the washing buffer was always PBS-BT.

The calibration curves for the microsphere-based method were fitted by GraphPad Prism Ver 5.0 using a 4-parameter logistic equation obtained with a nonlinear regression fitting procedure:

$$
\begin{aligned}
\mathrm{Y}= & R_{\mathrm{hi}}+\left(R_{\mathrm{lo}}-R_{\mathrm{hi}}\right) /\left(1+10^{\wedge}[\{\log \mathrm{IC} 50-X\}\right. \\
& \times \text { HillSlope }])
\end{aligned}
$$

where $R_{\mathrm{hi}}$ is the bottom or the response at infinite concentration, $R_{\mathrm{lo}}$ is the top or the response at 0 concentration, IC50 is the half maximal inhibitory concentration, and $X$ is the logarithm of concentration to base 10 .

Limits of detection (LODs) for multiplexed calibration curves were estimated using the $20 \%$ inhibitory concentration [32,43-45]: $0.61 \pm 0.21 \mu \mathrm{g} / \mathrm{L}$ for MCs, $0.67 \pm 0.08 \mu \mathrm{g} / \mathrm{L}$ for CYNs, $6.59 \pm 2.07 \mu \mathrm{g} / \mathrm{L}$ for ATX-a toxins, and $1.33 \pm 0.32 \mu \mathrm{g} / \mathrm{L}$ for DA (Figure $2 \mathrm{~A}-\mathrm{D}$ ).

For the microsphere-based method, methanol was evaporated to avoid interferences with organic solvents, as described in previously published immuno-detection methods $[41,46]$. After reconstitution in a buffer solution, the samples were checked for the presence of each analyte among the dynamic range of the detection curves done for each experiment (Figure 2).

\section{UPLC-MS/MS analysis}

The UPLC-MS/MS analyses were performed with a combination of UPLC with a mass detector. The UPLC system (Shimadzu) consisted of 2 pumps (LC-30AD), an autoinjector (SIL-10AC) with refrigerated rack, a degasser (DGU-20A), a column oven (CTO-10AS), and a system controller (SCL10Avp). This system was coupled to a MS/MS system (model 8040; Shimadzu). The nitrogen generator was a Nitrocraft NCLC/MS from Air Liquide.

The Aquity HSS T3 column $(100 \mathrm{~mm} \times 2.1 \mathrm{~mm}$ inner diameter; Waters), $1.8 \mu \mathrm{m}$, was used for cyanotoxins separations. The temperature was set at $35^{\circ} \mathrm{C}$. The composition of the
Table 2. Precursor and transitions (mass-to-charge ratio $[\mathrm{m} / \mathrm{z}]$ ) of

\begin{tabular}{|c|c|c|c|}
\hline Compound name & $\begin{array}{l}\text { Molecular } \\
\text { weight }\end{array}$ & $\begin{array}{l}\text { Transitions } \\
(\mathrm{m} / \mathrm{z})\end{array}$ & $\begin{array}{c}\text { Collision energy } \\
(\mathrm{eV})\end{array}$ \\
\hline $\mathrm{H}_{2}$-homoATX-a & 181 & $\begin{array}{l}182>164 \\
182>147\end{array}$ & $\begin{array}{l}-18 \\
-20\end{array}$ \\
\hline $\mathrm{H}_{2}$-ATX-a & 167 & $\begin{array}{l}168>150 \\
168>133\end{array}$ & $\begin{array}{l}-18 \\
-20\end{array}$ \\
\hline $\begin{array}{l}\text { Epoxy- } \\
\text { homoATX-a }\end{array}$ & 195 & $196>178$ & -18 \\
\hline & & $196>138$ & -20 \\
\hline ATX-a & 165 & $\begin{array}{r}166>166 \\
166>149 \\
166>131 \\
166>43\end{array}$ & $\begin{array}{r}-5 \\
-18 \\
-20 \\
-24\end{array}$ \\
\hline Epoxy-ATX-a & 181 & $\begin{array}{l}182>164 \\
182>138\end{array}$ & $\begin{array}{l}-18 \\
-20\end{array}$ \\
\hline homoATX-a & 179 & $\begin{array}{l}180>163 \\
180>145\end{array}$ & $\begin{array}{l}-18 \\
-20\end{array}$ \\
\hline DA & 311 & $\begin{array}{l}312>266 \\
312>161\end{array}$ & $\begin{array}{l}-20 \\
-30\end{array}$ \\
\hline MC-RR & 1038 & $\begin{array}{r}1039>1039 \\
1039>135 \\
520>135\end{array}$ & $\begin{array}{l}-15 \\
-74 \\
-35\end{array}$ \\
\hline MC-YR & 1045 & $\begin{array}{r}1046>1046 \\
1046>135\end{array}$ & $\begin{array}{l}-15 \\
-74\end{array}$ \\
\hline MC-LR & 995 & $\begin{array}{l}996>996 \\
996>135\end{array}$ & $\begin{array}{l}-15 \\
-74\end{array}$ \\
\hline MC-LA & 910 & $\begin{array}{l}911>911 \\
911>135\end{array}$ & $\begin{array}{l}-15 \\
-74\end{array}$ \\
\hline MC-LY & 1002 & $\begin{array}{r}1003>1003 \\
1003>135\end{array}$ & $\begin{array}{l}-15 \\
-74\end{array}$ \\
\hline MC-LW & 1025 & $\begin{array}{r}1026>1026 \\
1026>135\end{array}$ & $\begin{array}{l}-15 \\
-74\end{array}$ \\
\hline MC-LF & 986 & $\begin{array}{l}987>987 \\
987>135\end{array}$ & $\begin{array}{l}-15 \\
-74\end{array}$ \\
\hline NOD & 825 & $\begin{array}{r}826>826 \\
826>135 \\
826>70\end{array}$ & $\begin{array}{r}-5 \\
-55 \\
-73\end{array}$ \\
\hline CYN & 415 & $\begin{array}{l}416>194 \\
416>176\end{array}$ & $\begin{array}{l}-36 \\
-40\end{array}$ \\
\hline
\end{tabular}
cyanotoxins and collision energy

homoATX-a $=$ homoanatoxin-a; ATX-a $=$ anatoxin-a; DA = domoic acid; $\mathrm{MC}=$ microcystin $; \mathrm{NOD}=$ nodularin $; \mathrm{CYN}=$ cylindrospermopsins.

mobile phase was water (A) and acetonitrile (B), both containing $0.05 \%$ formic acid. Chromatographic separation was performed by gradient elution $(12.5 \mathrm{~min})$ starting with $2 \%$ of $\mathrm{B}$ for $4 \mathrm{~min}$; then $70 \% \mathrm{~B}$ was held for $1 \mathrm{~min}$, reduced to $2 \% \mathrm{~B}$ over $0.5 \mathrm{~min}$, and held for $3 \mathrm{~min}$ until the next run. The mobile phase flow rate was $0.45 \mathrm{~mL} / \mathrm{min}$, and the injection volume was $5 \mu \mathrm{L}$. The electrospray ionization source of the 8040 mass spectrometer was operated with the following optimized values of source-dependent parameters: nebulizing gas flow, $2 \mathrm{~L} / \mathrm{min}$; Desolvation Line (DL) temperature, $300{ }^{\circ} \mathrm{C}$; heat block temperature, $500{ }^{\circ} \mathrm{C}$; and drying gas flow, $15 \mathrm{~L} / \mathrm{min}$. The mass spectrometer was operated in positive multiple-reaction monitoring mode, analyzing the transitions shown in Table 2. The collision energy was optimized for each transition [33].

\begin{tabular}{|c|c|c|c|c|}
\hline Toxin & Retention time (min) & {$[\mathrm{M}+\mathrm{H}]^{+}$} & {$\left[\mathrm{M}-\mathrm{NH}_{3}+\mathrm{H}\right]^{+}$} & {$\left[\mathrm{M}-\mathrm{NH}_{3}-\mathrm{H}_{2} \mathrm{O}+\mathrm{H}\right]^{+}$} \\
\hline ATX-a & 2.8 & 166 & 149 & 131 \\
\hline H2-ATX-a & 2.3 & 165 & 151 & 133 \\
\hline H2-homoATX-a & 1.2 & 182.9 & 162.9 & 147 \\
\hline
\end{tabular}

Table 3. Typical losses and retention times of ATX-a toxins

ATX-a = anatoxin-a; $\mathrm{H}_{2}$-homoATX-a and $\mathrm{H}_{2}$-ATX-a = dihydro derivatives of anatoxin-a. 


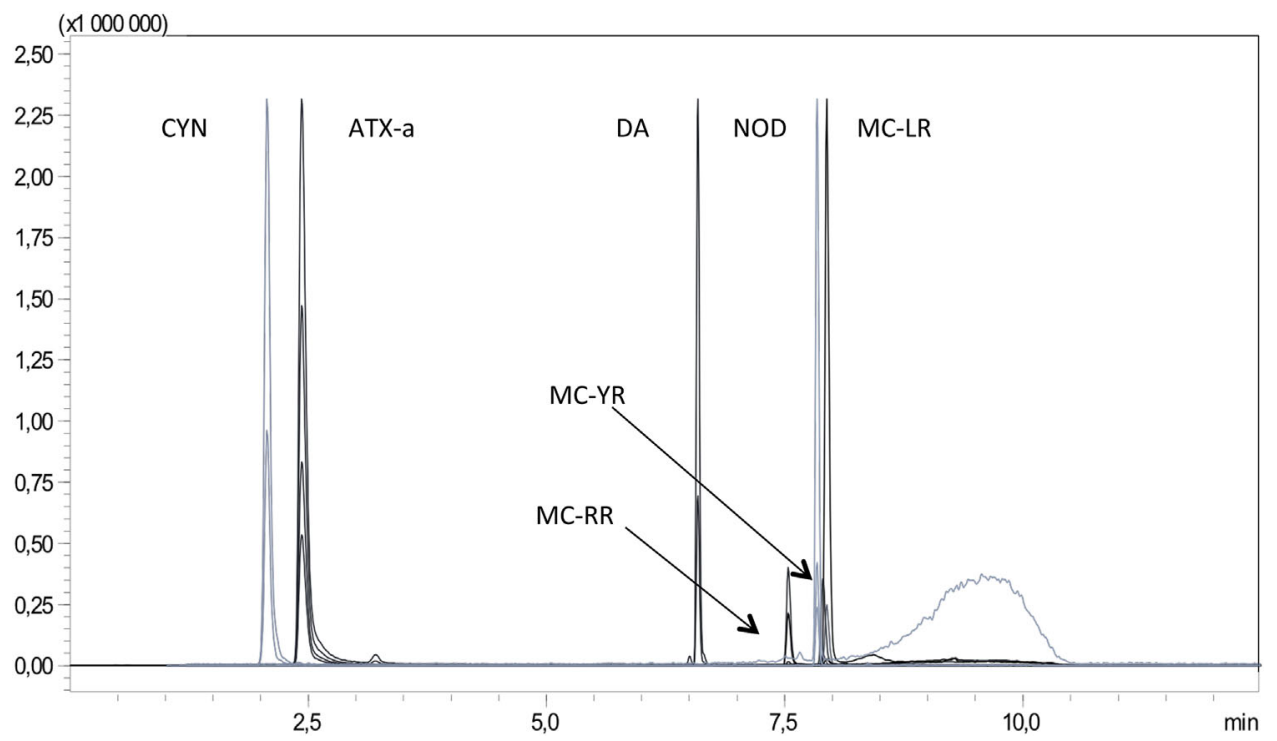

Figure 3. Chromatogram in positive multiple-reaction monitoring mode of standard solution in water: cylindrospermopsin $(\mathrm{CYN} ; 500 \mathrm{ng} / \mathrm{mL})$, anatoxin-a (ATX-a; $200 \mathrm{ng} / \mathrm{mL}$ ), microcystin-LR (MC-LR; $500 \mathrm{ng} / \mathrm{mL}$ ), microcystin-YR (MC-YR; $500 \mathrm{ng} / \mathrm{mL}$ ), microcystin-RR (MC-RR; $500 \mathrm{ng} / \mathrm{mL}$ ), nodularin (NOD; $500 \mathrm{ng} / \mathrm{mL})$, and domoic acid (DA; $500 \mathrm{ng} / \mathrm{mL})$.

The transitions of several toxins analogues, widely described in the literature, were added to the mass method, although no standards are available (Table 2). Similarly, following the fragmentation pathway of ATX-a, the analogues homoATX-a, $\mathrm{H}_{2}$-ATX-a, and $\mathrm{H}_{2}$-homoATX-a were added. Because no standards were available for some of these ATX-a analogues, in case of positive results, the product ion scan for each peak was done to confirm the identification, and the spectrums obtained showed the typical losses and structures of protonated compounds (Table 3). The identification of ATX-a analogues was done based on the molecular mass and the ionization pattern of each analogue, according to the bibliography. Given that the fragmentation pathway of each molecule is a tool often used to identify and confirm the presence of ATX-a analogues $[33,47,48]$. In addition to the fragmentation pathway, the chromatographic separation facilitated the differentiation of molecules. In this case, ATX-a, homoATX-a, $\mathrm{H}_{2}-\mathrm{ATX}-\mathrm{a}$ and $\mathrm{H}_{2}$-homoATX-a have the same losses. First a molecule of $\mathrm{NH}_{3}$ and then a molecule of water were lost; that is, $\left[\mathrm{M}-\mathrm{NH}_{3}+\mathrm{H}\right]^{+}$ and $\left[\mathrm{M}-\mathrm{NH}_{3}-\mathrm{H}_{2} \mathrm{O}+\mathrm{H}\right]^{+}$ions appeared.

The LOD and limit of quantification (LOQ) for each toxin were: LOD (ATX-a), $0.0038 \mu \mathrm{g} / \mathrm{L}$; LOD (CYN), $0.006 \mu \mathrm{g} / \mathrm{L}$; LOD (DA), $0.005 \mu \mathrm{g} / \mathrm{L}$; LOD (MCs and NOD), $0.0078 \mu \mathrm{g} / \mathrm{L}$; LOQ (ATX-a), $0.01 \mu \mathrm{g} / \mathrm{L}$; and LOQ (CYN, NOD, DA, and MCs), $0.02 \mu \mathrm{g} / \mathrm{L}$. No matrix effect in water sample was observed. The percentage (\%) of recovery in water higher than $90 \%$.

\section{RESULTS AND DISCUSSION}

Field samples (150) from different countries, encompassing a wide range of different habitats, were screened for the presence of freshwater toxins using both the microsphere-based assay and the UPLC-MS/MS method (Table 1). Because the microsphere-based and the UPLC-MS/MS methods were already described and validated elsewhere as reported in the Materials and Methods section, we intend only to compare the toxin profile obtained by each method (screening and analytical), focusing on the toxin diversity of the samples rather than comparing the methods. Each sample was extracted following a simple protocol and dissolved in methanol before
Table 4. Samples from France ${ }^{a}$

\begin{tabular}{|c|c|c|c|}
\hline \multirow[b]{2}{*}{ Code } & \multirow{2}{*}{$\frac{\text { Microsphere assay }}{\operatorname{ATX}-\mathrm{a}(\mu \mathrm{g} / \mathrm{L})}$} & \multicolumn{2}{|c|}{ UPLC-MS/MS } \\
\hline & & $\mathrm{H}_{2}$-homoATX-a $(\mu \mathrm{g} / \mathrm{L})$ & $\mathrm{H}_{2}$-ATX-a $(\mu \mathrm{g} / \mathrm{L})$ \\
\hline F7 & 0.928 & 0.0192 & 0.0525 \\
\hline F8 & 0.018 & 0.0283 & 0.0470 \\
\hline F9 & 0.618 & 0.0100 & 0.0439 \\
\hline F10 & 0.948 & & 0.0612 \\
\hline F11 & 0.578 & & 0.0525 \\
\hline F12 & 0.038 & 0.0149 & 0.0393 \\
\hline F13 & 0.448 & 0.0146 & 0.0493 \\
\hline F14 & & 0.0116 & 0.0445 \\
\hline F15 & 0.038 & 0.0101 & 0.0498 \\
\hline F16 & 0.408 & 0.0100 & 0.0600 \\
\hline F18 & 1.098 & & 0.0465 \\
\hline F19 & 0.038 & & 0.0486 \\
\hline F20 & 0.058 & 0.0100 & 0.0657 \\
\hline F21 & 0.008 & 0.0247 & 0.0552 \\
\hline F22 & 0.348 & 0.0239 & 0.0461 \\
\hline F24 & 1.908 & 0.0100 & 0.0549 \\
\hline F25 & 0.028 & 0.0100 & 0.0329 \\
\hline F26 & 1.368 & & 0.0478 \\
\hline F27 & 0.378 & & \\
\hline F28 & 2.118 & & \\
\hline F29 & 0.458 & $<\mathrm{LOQ}$ & 0.0294 \\
\hline F30 & 0.368 & & \\
\hline F31 & 5.308 & $<\mathrm{LOQ}$ & 0.0261 \\
\hline F32 & 1.868 & & \\
\hline F33 & 5.458 & & \\
\hline F34 & 5.458 & & \\
\hline F35 & 2.418 & & \\
\hline F36 & 0.928 & & 0.0460 \\
\hline F37 & 3.908 & $<\mathrm{LOQ}$ & 0.0651 \\
\hline F38 & 4.048 & 0.0112 & 0.0679 \\
\hline F39 & 3.218 & $<\mathrm{LOQ}$ & 0.0591 \\
\hline F43 & & $<\mathrm{LOQ}$ & 0.0560 \\
\hline F45 & & $<\mathrm{LOQ}$ & 0.0883 \\
\hline F49 & & $<\mathrm{LOQ}$ & 0.0761 \\
\hline F50 & & $<\mathrm{LOQ}$ & 0.0712 \\
\hline F52 & 0.498 & $<\mathrm{LOQ}$ & 0.0465 \\
\hline F53 & 0.988 & 0.0137 & 0.0549 \\
\hline
\end{tabular}

${ }^{\mathrm{a}}$ Positive results ( $\mu \mathrm{g}$ toxin/ $\mathrm{L}$ water collected) of samples collected in France in 2011 and 2013 analyzed by microsphere-based assay and ultraperformance liquid chromatography-tandem mass spectrometry (UPLCMS/MS) method.

ATX-a = anatoxin-a; $\mathrm{H}_{2}$-homoATX-a and $\mathrm{H}_{2}$-ATX-a = dihydro derivatives of anatoxin-a; $\angle \mathrm{LOQ}=$ traces below the limit of quantification. 
Table 5. Samples from Germany ${ }^{\mathrm{a}}$

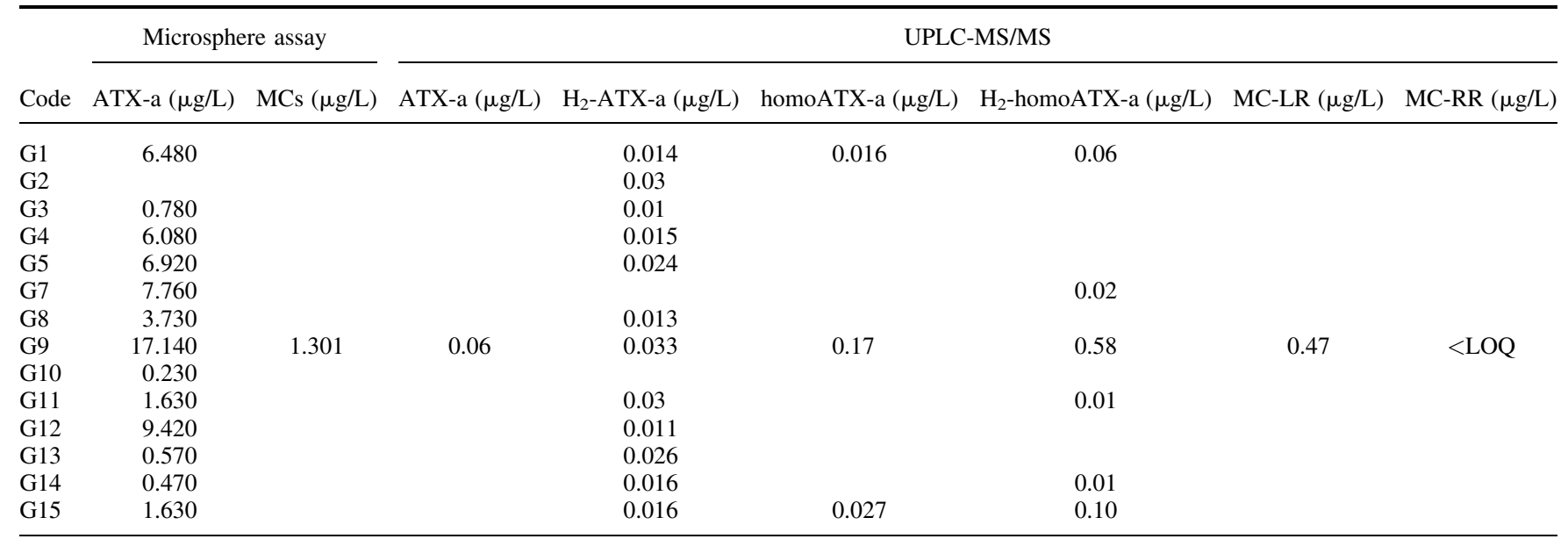

${ }^{a}$ Positive results ( $\mu \mathrm{g}$ toxin/L water collected) of samples collected in Germany in 2013 and 2014 analyzed by microsphere-based assay and ultra-performance liquid chromatography-tandem mass spectrometry (UPLC-MS/MS) method.

ATX-a = anatoxin-a; MCs = microcystins; $\mathrm{H}_{2}$-homoATX-a, homoATX-a and $\mathrm{H}_{2}-\mathrm{ATX}-\mathrm{a}=$ dihydro derivatives of anatoxin-a; $<\mathrm{LOQ}=$ traces below the limit of quantification.

analysis, and the presence of MCs, NODs, CYNs, Das, and ATX-a toxins was tested from the same extracts.

The presence of freshwater toxins was also assessed by UPLC-MS/MS using a method previously developed [33]. Using this method, CYN, NOD, DA, ATX-a, MC-RR, MC-YR, and MC-LR could be quantified with good separation between peaks in $12.5 \mathrm{~min}$ (Figure 3). In addition, the amino acid phenylalanine was also separated to avoid misidentifications between ATX-a and this compound [33].

The environmental samples with positive toxin results by microsphere-based multidetection method or from UPLC-MS/ MS are shown in Tables 4-8. No toxins were detected in samples F1 through F6 from France, which encompass 6 mo of municipal tap water samples collected from January to November 2013. As such, these samples were allocated as negative controls for both detection methods. No traces of CYN or DA were detected in any of the samples. In water bodies from Spain and Greece, CYN had been detected previously [49,50]. However, this toxin is not regularly identified in Europe. In the case of DA, although some species producing this toxin have been described in brackish waters (and are usually identified in estuaries and bay waters, where the salinity is not as high as in marine environments), to our knowledge the toxin has never been reported in fresh waters [27,51,52]. The present results suggest that these 2 toxins currently are not a risk in European waters sampled. Similarly, no traces of NOD were detected in any of the samples analyzed.

The same results were obtained for MCs in samples collected from France and Ireland. In samples collected in Germany, however, several MCs analogues were detected using the microspheres assay (Table 5). Within this assay, $1.30 \mu \mathrm{g} / \mathrm{L}$ of MCs were detected in sample G9 obtained from a lake in summer 2013, whereas no MCs were found in the remaining samples. When this sample was analyzed by UPLC-MS/MS, $0.47 \mu \mathrm{g} / \mathrm{L}$ of MC-LR and traces of MC-RR were detected. In general, MC levels were rather low, especially considering previous findings that show MCs in $24 \%$ of lakes in Germany, with up to $560 \mu \mathrm{g} / \mathrm{L}$ in extreme conditions [53]. These toxins were also detected in sample I4 from Italy, obtained from a lake in autumn 2012, measured by the microspheres assay; however no toxins were detected by UPLC-MS/MS when this sample was confirmed (Table 7). In several samples from Turkey, high levels of MCs were also detected by microspheres assay, but only MC-RR was found by UPLC-MS/MS in sample T7 (Table 8). Discrepancies between these methods can be attributed to antibody/assay cross-reactivity [32]. In samples from Turkey, some matrix interference in the microspheres assay could have taken place in addition to the cross-reactivity, since MCs were detected in 7 samples from 20, whereas no toxins were detected by UPLC-MS/MS. In the same way, matrix interferences have been described to produce false positives when commercial enzyme-linked immunosorbent assay kits for MCs and NODs were used to check tap and lake waters or when the salinity of the samples was increased [46,54].

Regarding ATX-a results, several conclusions can be drawn. From the microsphere-based assay data, ATX-a or some analogue seems to be present in a high number of samples (81 of 119). These observations were confirmed when the samples were analyzed by UPLC-MS/MS, because the presence of $\mathrm{H}_{2}$ ATX-a and $\mathrm{H}_{2}$-homoATX-a was observed in 113 of the 150 samples. Although the amount quantified was not exactly the same, in 96 of 119 samples analyzed by both methods, ATX-a analogues were detected; none of the target toxins were found in 23 of the samples. Interestingly, 15 samples were negative based on the microspheres method but were positive by UPLC-MS/ MS; and 14 were negative by UPLC-MS/MS but were positive within the microspheres assay. Moreover, 31 samples were analyzed only by UPLC-MS/MS, and positive results for $\mathrm{H}_{2-}$ ATX-a and for $\mathrm{H}_{2}$-homoATX-a were found. The discrepancies between the amounts quantified by both methods could be caused by a different affinity of ATX-a analogues for the protein involved in the microspheres assay. In addition, the higher number of these discrepancies occurred with samples from brackish waters, where the matrix interference has been described [46,54]. However the good equivalence between positives and negatives in samples analyzed by both methods (75\%) supports the microspheres method as a reliable tool to detect the presence of ATX-a toxins as a prior screening, at least in fresh water. On the other hand, the detection of $\mathrm{H}_{2}$-ATX-a and $\mathrm{H}_{2}$-homoATX-a in all localities is a very important result 
Table 6. Samples for Ireland ${ }^{\mathrm{a}}$

\begin{tabular}{|c|c|c|c|}
\hline \multirow[b]{2}{*}{ Code } & \multirow{2}{*}{$\begin{array}{c}\begin{array}{c}\text { Microsphere } \\
\text { assay }\end{array} \\
\begin{array}{c}\text { ATX-a } \\
(\mu \mathrm{g} / \mathrm{L})\end{array}\end{array}$} & \multicolumn{2}{|c|}{ UPLC-MS/MS } \\
\hline & & $\underset{(\mu \mathrm{g} / \mathrm{L})}{\mathrm{H}_{2} \text {-homoATX-a }}$ & $\begin{array}{c}\mathrm{H}_{2} \text {-ATX-a } \\
(\mu \mathrm{g} / \mathrm{L})\end{array}$ \\
\hline IR1 & 0.750 & 0.0414 & 0.1044 \\
\hline IR3 & 0.309 & $<\mathrm{LOQ}$ & 0.1134 \\
\hline IR5 & 0.174 & $<\mathrm{LOQ}$ & 0.1095 \\
\hline IR6 & 0.747 & $<\mathrm{LOQ}$ & 0.0896 \\
\hline IR7 & & $<\mathrm{LOQ}$ & 0.0965 \\
\hline IR8 & 0.254 & $<\mathrm{LOQ}$ & 0.0905 \\
\hline IR9 & 0.245 & $<\mathrm{LOQ}$ & 0.1177 \\
\hline IR10 & 0.445 & $<$ LOQ & 0.1137 \\
\hline IR $11^{b}$ & & $<\mathrm{LOQ}$ & 0.1024 \\
\hline IR $12^{b}$ & & $<\mathrm{LOQ}$ & 0.0782 \\
\hline IR $13^{b}$ & & $<$ LOQ & 0.1083 \\
\hline IR $14^{\mathrm{b}}$ & & $<$ LOQ & 0.1375 \\
\hline IR $15^{b}$ & & $<$ LOQ & 0.0794 \\
\hline IR16 ${ }^{\mathrm{b}}$ & & & 0.0987 \\
\hline IR17 $7^{\mathrm{b}}$ & & & 0.0951 \\
\hline IR $18^{\mathrm{b}}$ & & & 0.0802 \\
\hline IR19 & 0.401 & $<\mathrm{LOQ}$ & 0.1004 \\
\hline IR21 & & $<\mathrm{LOQ}$ & 0.0796 \\
\hline IR23 & & $<\mathrm{LOQ}$ & 0.0781 \\
\hline IR24 & & & 0.0792 \\
\hline IR25 & & & 0.0541 \\
\hline IR26 & & & 0.0575 \\
\hline IR27 & & & 0.0706 \\
\hline IR28 & & & 0.0858 \\
\hline IR29 & & & 0.0780 \\
\hline IR $30^{b}$ & & $<\mathrm{LOQ}$ & 0.0796 \\
\hline $\operatorname{IR} 31^{\mathrm{b}}$ & & 0.0205 & 0.0855 \\
\hline IR $32^{\mathrm{b}}$ & & $<\mathrm{LOQ}$ & 0.0586 \\
\hline IR33 ${ }^{\mathrm{b}}$ & & $<\mathrm{LOQ}$ & 0.1013 \\
\hline IR $34^{\mathrm{b}}$ & & $<\mathrm{LOQ}$ & 0.0810 \\
\hline IR $35^{\mathrm{b}}$ & & $<$ LOQ & 0.0813 \\
\hline IR $36^{\mathrm{b}}$ & & $<\mathrm{LOQ}$ & 0.0890 \\
\hline $\operatorname{IR} 37^{\mathrm{b}}$ & & $<\mathrm{LOQ}$ & 0.0570 \\
\hline IR38 & 1.387 & 0.0447 & 0.0881 \\
\hline IR39 & 0.139 & & \\
\hline IR43 & 0.022 & & \\
\hline IR44 & 0.189 & & \\
\hline IR45 & 0.751 & & \\
\hline IR47 & 0.061 & $<\mathrm{LOQ}$ & 0.0887 \\
\hline IR $48^{\mathrm{b}}$ & & 0.0249 & 0.0873 \\
\hline IR49 & & 0.0262 & 0.0876 \\
\hline IR50 & & 0.0181 & 0.0912 \\
\hline IR $51^{b}$ & & 0.0031 & 0.0749 \\
\hline IR52 & & $<\mathrm{LOQ}$ & 0.0550 \\
\hline IR5 $3^{\mathrm{b}}$ & & & 0.0848 \\
\hline IR5 $4^{\mathrm{b}}$ & & & 0.0931 \\
\hline IR5 $5^{\mathrm{b}}$ & & $<\mathrm{LOQ}$ & 0.0837 \\
\hline
\end{tabular}

${ }^{\mathrm{a}}$ Positive results ( $\mu \mathrm{g}$ toxin/L water collected) of samples collected in Ireland in 2012 and 2014 analyzed by microsphere-based assay and ultraperformance liquid chromatography-tandem mass spectrometry (UPLCMS/MS) method.

${ }^{b}$ Analyzed only by UPLC-MS/MS

ATX-a = anatoxin-a; $\mathrm{H}_{2}$-homoATX-a and $\mathrm{H}_{2}-\mathrm{ATX}-\mathrm{a}=$ dihydro derivatives of anatoxin-a; $\angle \mathrm{LOQ}=$ traces below the limit of quantification.

described for the first time from the present study. Whereas ATX-a was detected in only 1 sample from Germany (G9) and homoATX-a was detected in 3 samples (G1, G9, and G15), the dihydro derivatives of these toxins were detected in almost all samples collected in the 5 countries involved. In this sense, $\mathrm{H}_{2}$ ATX-a was detected in most samples and in higher amounts. The toxins $\mathrm{H}_{2}$-ATX-a and $\mathrm{H}_{2}$-homoATX-a were considered as degradation products of ATX-a and homoATX-a, respectively [47]. However, enzymatic steps to produce this degradation are still largely unknown, and the dihydro derivatives sometimes represent a higher percentage of the
Table 7. Samples for Italy ${ }^{\mathrm{a}}$

\begin{tabular}{llllcc}
\hline & \multicolumn{2}{c}{ Microsphere Assay } & & \multicolumn{2}{c}{ UPLC-MS/MS } \\
\cline { 2 - 3 } \cline { 5 - 6 } Code & $\begin{array}{c}\text { ATX-a } \\
(\mu \mathrm{g} / \mathrm{L})\end{array}$ & $\begin{array}{c}\text { MCs } \\
(\mu \mathrm{g} / \mathrm{L})\end{array}$ & & $\begin{array}{c}\mathrm{H}_{2} \text {-homoATX-a } \\
(\mu \mathrm{g} / \mathrm{L})\end{array}$ & $\begin{array}{c}\mathrm{H}_{2} \text {-ATX-a } \\
(\mu \mathrm{g} / \mathrm{L})\end{array}$ \\
\hline $\mathrm{I} 1$ & 3.815 & & & 0.0345 & 0.0174 \\
$\mathrm{I} 2$ & 0.603 & & & $<$ LOQ & 0.0746 \\
$\mathrm{I} 3$ & 0.560 & & & & 0.0751 \\
$\mathrm{I} 4$ & 1.750 & 1.295 & & $<\mathrm{LOQ}$ & 0.0712 \\
$\mathrm{I} 5$ & 0.294 & & & 0.0167 & 0.0687 \\
$\mathrm{I} 6$ & 0.920 & & & 0.0697 \\
\hline
\end{tabular}

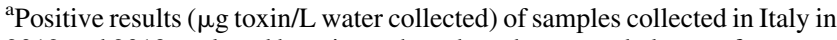
2012 and 2013 analyzed by microsphere-based assay and ultra-performance liquid chromatography-tandem mass spectrometry (UPLC-MS/MS) method.

ATX-a $=$ anatoxin-a; MCs $=$ microcystins; $\mathrm{H}_{2}$-homoATX-a and $\mathrm{H}_{2}$-ATX$\mathrm{a}=$ dihydro derivatives of anatoxin- $\mathrm{a} ;<\mathrm{LOQ}=$ traces below the limit of quantification.

total toxin content in field samples [26,55]. In addition, the cluster of genes responsible of the natural production of dihydro toxins was recently identified in several cyanobacteria [18]. Therefore, the wide distribution of dihydro derivatives with respect to the ATX-a and homoATX-a observed in our results points to their natural occurrence. These toxins are neurotoxic compounds responsible for many animal poisonings worldwide [23,56]. Anatoxin-a is transformed into a non-toxic compound after sunlight exposure, and the dihydro derivatives show an approximately 10 -fold reduction of affinity for nicotinic receptors and lower toxicity [2,55]. Because of the lack of standards, however, no studies about toxicity and transformations of pure dihydro compounds are available; therefore, the toxicological risk of these compounds is unknown. Although there are no official guidelines for maximum levels of ATX-a in drinking waters in Europe, several US states have implemented threshold levels for this toxin. In addition, the US EPA has recently published a health effects support document for ATX-a [57], but there is not adequate information to support a health advisory for these toxins, ATX-a, and derivatives, as that which exists for MCs and CYN [7,57]. Therefore, considering the present study, ATX-a toxins and especially the dihydro derivatives should be taken under consideration in future regulations and monitoring protocols for water quality, because all of them are naturally present everywhere in Europe and their potential health risk should be assessed.

\section{CONCLUSIONS}

The toxins MCs, ATX-a, homoATX-a, and mainly $\mathrm{H}_{2}$-ATXa and $\mathrm{H}_{2}$-homoATX-a are present in aquatic habitats throughout Europe. The wide natural distribution of dihydro derivatives of ATX-a toxins is an important issue that should be taken under consideration in monitoring programs to avoid intoxications. The combination of 2 multidetection assays - the microspherebased method, as a screening assay, and the analytical method UPLC-MS/MS, which requires highly trained personnelmight be a useful approach to monitoring freshwater toxins in a sampling program. Nevertheless, the microsphere-based method as a semi-quantitative approximation to detect the toxins seems to require further refining of antibodies cross reactivity. This initial screening indicates presence or absence of toxins and reduces the number of samples to be analyzed by 
Table 8. Samples from Turkey ${ }^{\mathrm{a}}$

\begin{tabular}{|c|c|c|c|c|c|}
\hline \multirow[b]{2}{*}{ Code } & \multicolumn{2}{|c|}{ Microsphere assay } & \multicolumn{3}{|c|}{ UPLC-MS/MS } \\
\hline & $\begin{array}{l}\text { ATX-a } \\
(\mu \mathrm{g} / \mathrm{L})\end{array}$ & $\begin{array}{l}\mathrm{MCs} \\
(\mu \mathrm{g} / \mathrm{L})\end{array}$ & $\begin{array}{c}\mathrm{H}_{2} \text {-homoATX-a } \\
(\mu \mathrm{g} / \mathrm{L})\end{array}$ & $\begin{array}{c}\mathrm{H}_{2}-\mathrm{ATX}-\mathrm{a} \\
(\mu \mathrm{g} / \mathrm{L})\end{array}$ & $\begin{array}{c}\text { MC-RR } \\
(\mu \mathrm{g} / \mathrm{L})\end{array}$ \\
\hline $\mathrm{T} 1$ & 0.557 & 0.101 & & $<\mathrm{LOQ}$ & \\
\hline $\mathrm{T} 2$ & 2.553 & & $<\mathrm{LOQ}$ & $<\mathrm{LOQ}$ & \\
\hline T3 & 0.094 & 0.418 & & & \\
\hline $\mathrm{T} 4$ & 0.081 & 0.900 & $<\mathrm{LOQ}$ & 0.079 & \\
\hline T5 & 0.168 & 1.487 & $<\mathrm{LOQ}$ & 0.075 & \\
\hline T6 & 0.207 & 2.068 & & & \\
\hline $\mathrm{T} 7$ & 0.080 & 1.384 & $<\mathrm{LOQ}$ & $<\mathrm{LOQ}$ & 0.191 \\
\hline T8 & 0.123 & 0.725 & $<\mathrm{LOQ}$ & 0.055 & \\
\hline T9 & 0.318 & & 0.021 & 0.075 & \\
\hline T10 & 0.096 & & $<\mathrm{LOQ}$ & 0.088 & \\
\hline T11 & 0.083 & 0.326 & $<\mathrm{LOQ}$ & 0.066 & \\
\hline $\mathrm{T} 12$ & 0.127 & 0.132 & $<$ LOQ & 0.066 & \\
\hline T13 & 1.474 & & $<\mathrm{LOQ}$ & 0.089 & \\
\hline $\mathrm{T} 14^{\mathrm{b}}$ & & & $<\mathrm{LOQ}$ & 0.079 & \\
\hline $\mathrm{T} 15^{\mathrm{b}}$ & & & $<\mathrm{LOQ}$ & 0.059 & \\
\hline $\mathrm{T} 16^{\mathrm{b}}$ & & & $<$ LOQ & 0.055 & \\
\hline $\mathrm{T} 17^{\mathrm{b}}$ & & & $<\mathrm{LOQ}$ & 0.035 & \\
\hline $\mathrm{T} 18^{\mathrm{b}}$ & & & 0.038 & 0.035 & \\
\hline $\mathrm{T} 19^{\mathrm{b}}$ & & & $<$ LOQ & 0.037 & \\
\hline $\mathrm{T} 20^{\mathrm{b}}$ & & & $<\mathrm{LOQ}$ & 0.041 & \\
\hline
\end{tabular}

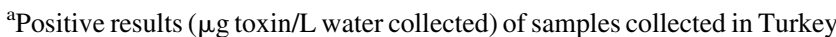
in 2012 and 2014 analyzed by microsphere-based assay and ultraperformance liquid chromatography-tandem mass spectrometry (UPLCMS/MS) method.

${ }^{\mathrm{b}}$ Analyzed only by UPLC-MS/MS

ATX-a $=$ anatoxin-a; MCs $=$ microcystins; $\mathrm{H}_{2}$-homoATX-a and $\mathrm{H}_{2}$-ATX$\mathrm{a}=$ dihydro derivatives of anatoxin- $\mathrm{a} ; \angle \mathrm{LOQ}=$ traces below the limit of quantification.

confirmatory analytical methods, which typically are more laborious. Therefore, the combination of methodologies described in the present study should reduce the number of samples and the time of analysis, especially since both methodologies are designed as multidetection assays.

Acknowledgment-The research leading to these results has received funding from the following FEDER cofunded-grants: from CDTI and Technological Funds, supported by Ministerio de Economía y Competitividad, AGL2012-40185-CO2-01, AGL2014-58210-R, and Consellería de Cultura, Educación e Ordenación Universitaria, GRC2013-016; and from the European Union's Seventh Framework Program managed by the Research Executive Agency (FP7/2007-2013), 265409 MicroAqua. I. Rodríguez is supported by a fellowship from Subprograma de Formación de Personal Investigador (AGL2012-40185-CO2-01), Spain. Authors participated in the present study as follows: I. Rodriguez: sample processing, UPLC-MS/MS analysis, table elaboration, and manuscript preparation; M. Fraga: sample processing, microsphere-assay analysis, and manuscript preparation; A. Alfonso and L.M. Botana: analysis design, data supervision, and manuscript elaboration. Collection of $50 \mathrm{~L}$ of water samples and concentration to $1 \mathrm{~L}$ was performed as follows: D. Guillebault, L. Medlin, and J. Baudart: samples from France (Canet Lagoon and Mondony River); P. Jacob and K. Helmi: samples from France (tap water, Sine River, Oise River, and Marne River); T. Meyer and U. Breitenbach: samples from Germany; N.M. Holden and B. Boots: samples from Ireland; R. Spurio, L. Cimarelli, L. Mancini, and S. Marcheggiani: samples from Italy; M. Albay, R. Akcaalan, and L. Köker: samples from Turkey.

Data availability -Data, associated metadata, and calculation tools are available from the corresponding author (amparo.alfonso@usc.es; Luis.Botana@usc.es).

\section{REFERENCES}

1. Chislock MF, Doster E, Zitomer RA Wilson A. 2013. Eutrophication: Causes, consequences, and controls in aquatic ecosystems. Nature Education Knowledge 4:10.
2. Merel S, Walker D, Chicana R, Snyder S, Baures E, Thomas O. 2013. State of knowledge and concerns on cyanobacterial blooms and cyanotoxins. Environ Int 59:303-327.

3. Hilborn ED, Beasley VR. 2015. One health and cyanobacteria in freshwater systems: Animal illnesses and deaths are sentinel events for human health risks. Toxins 7:1374-1395.

4. World Health Organization. 1998. Guidelines for Drinking-Water Quality, 2nd ed. Addendum to Volume 2: Health criteria and other supporting information. Geneva, Switzlerand.

5. Burch MD. 2008. Effective doses, guidelines \& regulations. Adv Exp Med Biol 619:831-853.

6. Chorus I, Bartram J. 1999. Toxic Cyanobacteria in Water: A Guide to their Public Health Consequences, Monitoring and Management. Spon Press, Oxfordhire, UK.

7. US Environmental Protection Agency. 2015. Drinking water health advisories for two cyanobacterial toxins. EPA 820/F-15/003. [cited 2016 February 16]. Available from: https://www.epa.gov/sites/ production/files/2015-06/documents/cyanotoxins-fact_sheet-2015.pdf

8. Merel S, Clément M, Thomas O. 2010. State of the art on cyanotoxins in water and their behaviour towards chlorine. Toxicon 55:677-691.

9. Pearson L, Mihali T, Moffitt M, Kellmann R, Neilan B. 2010. On the chemistry, toxicology and genetics of the cyanobacterial toxins, microcystin, nodularin, saxitoxin and cylindrospermopsin. Mar Drugs 8:1650-1680.

10. Pereira P, Onodera H, Andrinolo DO, Franca S, Araújo F, Lagos N, Oshima Y. 2000. Paralytic shellfish toxins in the freshwater cyanobacterium Aphanizomenon flos-aquae, isolated from Montargil reservoir, Portugal. Toxicon 38:1689-1702.

11. Chen Y, Shen D, Fang D. 2013. Nodularins in poisoning. Clin Chim Acta 425:18-29.

12. Eriksson JE, Meriluoto JAO, Kujari HP, Österlund K, Fagerlund K, Hällbom L. 1988. Preliminary characterization of a toxin isolated from the cyanobacterium Nodularia spumigena. Toxicon 26:161-166.

13. Moreira C, Azevedo J, Antunes A, Vasconcelos V. 2013. Cylindrospermopsin: Occurrence, methods of detection and toxicology. $J$ Appl Microbiol 114:605-620.

14. Banker R, Carmeli S, Werman M, Teltsch B, Porat R, Sukenik A. 2001. Uracil moiety is required for toxicity of the cyanobacterial hepatotoxin cylindrospermopsin. J Toxicol Environ Health A 62:281-288.

15. Norris RL, Eaglesham GK, Pierens G, Shaw GR, Smith MJ, Chiswell RK, Seawright AA, Moore MR. 1999. Deoxycylindrospermopsin, an analog of cylindrospermopsin from Cylindrospermopsis raciborskii. Environ Toxicol 14:163-165.

16. Lopez-Alonso H, Rubiolo JA, Vega F, Vieytes MR, Botana LM. 2013. Protein synthesis inhibition and oxidative stress induced by cylindrospermopsin elicit apoptosis in primary rat hepatocytes. Chem Res Toxicol 26:203-212.

17. Terao K, Ohmori S, Igarashi K, Ohtani I, Watanabe MF, Harada KI, Ito E, Watanabe M. 1994. Electron microscopic studies on experimental poisoning in mice induced by cylindrospermopsin isolated from bluegreen alga Umezakia natans. Toxicon 32:833-843.

18. Mejean A, Paci G, Gautier V, Ploux O. 2014. Biosynthesis of anatoxina and analogues (anatoxins) in cyanobacteria. Toxicon 91:15-22.

19. Viaggiu E, Melchiorre S, Volpi F, Di Corcia A, Mancini R, Garibaldi L, Crichigno G, Bruno M. 2004. Anatoxin-a toxin in the cyanobacterium Planktothrix rubescens from a fishing pond in northern Italy. Environ Toxicol 19:191-197.

20. Spivak CE, Witkop B, Albuquerque EX. 1980. Anatoxin-a: A novel, potent agonist at the nicotinic receptor. Mol Pharmacol 18:384-394.

21. Thomas P, Stephens M, Wilkie G, Amar M, Lunt GG, Whiting P, Gallagher T, Pereira E, Alkondon M, Albuquerque EX, Wonnacott S. 1993. (+)-Anatoxin-a is a potent agonist at neuronal nicotinic acetylcholine receptors. $J$ Neurochem 60:2308-2311.

22. Wonnacott S, Swanson KL, Albuquerque EX, Huby NJS, Thompson P, Gallagher T. 1992. Homoanatoxin: A potent analogue of anatoxin-a. Biochem Pharmacol 43:419-423.

23. Osswald J, Rellan S, Gago A, Vasconcelos V. 2007. Toxicology and detection methods of the alkaloid neurotoxin produced by cyanobacteria, anatoxin-a. Environ Int 33:1070-1789.

24. James KJ, Furey A, Sherlock IR, Stack MA, Twohig M, Caudwell FB, Skulberg OM. 1998. Sensitive determination of anatoxin-a, homoanatoxin-a and their degradation products by liquid chromatography with fluorimetric detection. J Chromatogr A 798:147-157.

25. Stevens DK, Krieger RI. 1991. Stability studies on the cyanobacterial nicotinic alkaloid anatoxin-A. Toxicon 29:167-179.

26. Mann S, Cohen M, Chapuis-Hugon F, Pichon V, Mazmouz R, Mejean A, Ploux O. 2012. Synthesis, configuration assignment, and simultaneous quantification by liquid chromatography coupled to tandem mass 
spectrometry, of dihydroanatoxin-a and dihydrohomoanatoxin-a together with the parent toxins, in axenic cyanobacterial strains and in environmental samples. Toxicon 60:1404-1414.

27. Kotaki Y, Lundholm N, Onodera H, Kobayashi K, Bajarias FFA, Furio EF, Iwataki M, Fukuyo Y, Kodama M. 2004. Wide distribution of Nitzschia navis-varingica, a new domoic acid-producing benthic diatom found in Vietnam. Fisheries Sci 70:28-32.

28. Clayden J, Read B, Hebditch KR. 2005. Chemistry of domoic acid, isodomoic acids, and their analogues. Tetrahedron 61:5713-5724.

29. Slevin JT, Collins JF, Coyle JT. 1983. Analogue interactions with the brain receptor labeled by [3H]kainic acid. Brain Res 265:169-172.

30. Lévesque B, Gervais M-C., Chevalier P, Gauvin D, Anassour-LaouanSidi E, Gingras S, Fortin N, Brisson G, Greer C, Bird D. 2014. Prospective study of acute health effects in relation to exposure to cyanobacteria. Sci Total Environ 466-467:397-403.

31. Moreira C, Ramos V, Azevedo J, Vasconcelos V. 2014. Methods to detect cyanobacteria and their toxins in the environment. Appl Microbiol Biotech 98:8073-8082.

32. Fraga M, Vilariño N, Louzao MC, Rodríguez LP, Alfonso A, Campbell K, Elliott CT, Taylor P, Ramos V, Vasconcelos V, Botana LM. 2014. Multi-detection method for five common microalgal toxins based on the use of microspheres coupled to a flow-cytometry system. Anal Chim Acta 850:57-64.

33. Rodriguez I, Alfonso C, Alfonso A, Otero P, Meyer T, Breitenbach U, Botana LM. 2014. Toxin profile in samples collected in fresh and brackish water in Germany. Toxicon 91:35-44.

34. Kim JS, Ligler FS. 2010. Utilization of microparticles in nextgeneration assays for microflow cytometers. Anal Bioanal Chem 398:2373-2382.

35. Devlin S, Meneely JP, Greer B, Greef C, Lochhead MJ, Elliott CT. 2013. Next generation planar waveguide detection of microcystins in freshwater and cyanobacterial extracts, utilising a novel lysis method for portable sample preparation and analysis. Anal Chim Acta 769:108-113.

36. Elliott CT, Redshaw CH, George SE, Campbell K. 2013. First development and characterisation of polyclonal and monoclonal antibodies to the emerging fresh water toxin cylindrospermopsin. Harmful Algae 24:10-19.

37. McGrath TF, Andersson K, Campbell K, Fodey TL, Elliott CT. 2013. Development of a rapid low cost fluorescent biosensor for the detection of food contaminants. Biosens Bioelectron 41:96-102.

38. Hansen SB, Radic Z, Talley TT, Molles BE, Deerinck T, Tsigelny I, Taylor P. 2002. Tryptophan fluorescence reveals conformational changes in the acetylcholine binding protein. J Biol Chem 277: 41299-41302.

39. Hansen SB, Talley TT, Radic Z, Taylor P. 2004. Structural and ligand recognition characteristics of an acetylcholine-binding protein from Aplysia californica. J Biol Chem 279:24197-24202.

40. Marcheggiani S, D’Ugo E, Puccinelli C, Giuseppetti R, D’Angelo AM, Gualerzi CO, Spurio R, Medlin LK, Guillebault D, Weigel W, Helmi K, Mancini L. 2015. Detection of emerging and re-emerging pathogens in surface waters close to an urban area. Int J Environ Res Public Health 12:5505-5527.

41. Fraga M, Vilarino N, Louzao MC, Rodriguez P, Campbell K, Elliott CT, Botana LM. 2013. Multidetection of paralytic, diarrheic, and amnesic shellfish toxins by an inhibition immunoassay using a microsphere-flow cytometry system. Anal Chem 85:7794-7802.

42. Rodriguez LP, Vilarino N, Molgo J, Araoz R, Louzao MC, Taylor P, Talley T, Botana LM. 2013. Development of a solid-phase receptor- based assay for the detection of cyclic imines using a microsphere-flow cytometry system. Anal Chem 85:2340-2407.

43. Campbell K, Haughey SA, van den Top H, van Egmond H, Vilariño N, Botana LM, Elliott CT. 2010. Single laboratory validation of a surface plasmon resonance biosensor screening method for paralytic shellfish poisoning toxins. Anal Chem 82:2977-2988.

44. Fraga M, Vilarino N, Louzao MC, Campbell K, Elliott CT, Kawatsu K, Vieytes MR, Botana LM. 2012. Detection of paralytic shellfish toxins by a solid-phase inhibition immunoassay using a microsphere-flow cytometry system. Anal Chem 84:4350-4356.

45. Usleber E, Dietrich R, Burk C, Schneider E, Martlbauer E. 2001. Immunoassay methods for paralytic shellfish poisoning toxins. J AOAC Int 84:1649-1656.

46. Metcalf JS, Hyenstrand P, Beattie KA, Codd GA. 2000. Effects of physicochemical variables and cyanobacterial extracts on the immunoassay of microcystin-LR by two ELISA kits. J Appl Microbiol 89:532-538.

47. James KJ, Crowley J, Hamilton B, Lehane M, Skulberg O, Furey A. 2005. Anatoxins and degradation products, determined using hybrid quadrupole time-of-flight and quadrupole ion-trap mass spectrometry: Forensic investigations of cyanobacterial neurotoxin poisoning. Rapid Commun Mass Spectrom 19:1167-1175.

48. Sanchez JA, Otero P, Alfonso A, Ramos V, Vasconcelos V, Araoz R, Molgo J, Vieytes MR, Botana LM. 2014. Detection of anatoxin-a and three analogs in anabaena spp. cultures: New fluorescence polarization assay and toxin profile by LC-MS/MS. Toxins 6:402-415.

49. Cires S, Wormer L, Ballot A, Agha R, Wiedner C, Velazquez D, Casero MC, Quesada A. 2014. Phylogeography of cylindrospermopsin and paralytic shellfish toxin-producing nostocales cyanobacteria from mediterranean europe (Spain). Appl Environ Microb 80: 1359-1370.

50. Gkelis S, Zaoutsos N. 2014. Cyanotoxin occurrence and potentially toxin producing cyanobacteria in freshwaters of Greece: A multidisciplinary approach. 78:1-9.

51. Ajani P, Brett S, Krogh M, Scanes P, Webster G, Armand L. 2013. The risk of harmful algal blooms (HABs) in the oyster-growing estuaries of New South Wales, Australia. Environ Monit Assess 185:5295-5316.

52. Trainer VL, Adams NG, Bill BD, Anulacion BF, Wekell JC. 1998. Concentration and dispersal of a Pseudo-nitzschia bloom in Penn Cove, Washington, USA. Natural toxins 6:113-126.

53. Frank CA. 2002. Microcystin-producing cyanobacteria in recreational waters in southwestern Germany. Environ Toxicol 17:361-366.

54. Triantis T, Tsimeli K, Kaloudis T, Thanassoulias N, Lytras E, Hiskia A. 2010. Development of an integrated laboratory system for the monitoring of cyanotoxins in surface and drinking waters. Toxicon 55:979-989.

55. Heath MW, Wood SA, Barbieri RF, Young RG, Ryan KG. 2014. Effects of nitrogen and phosphorus on anatoxin-a, homoanatoxin-a, dihydroanatoxin-a and dihydrohomoanatoxin-a production by Phormidium autumnale. Toxicon 92:179-185.

56. Quiblier C, Wood SA, Echenique-Subiabre I, Heath MW, Villeneuve A, Humbert JF. A review of current knowledge on toxic benthic freshwater cyanobacteria-Ecology, toxin production and risk management. Water Res 47:5464-5479.

57. US Environmental Protection Agency. 2015. Health effects support document for the cyanobacterial toxin anatoxin-a. EPA 820/R-15/104. [cited 2016 February 16]. Available from: http://water.epa.gov/drink/ standards/hascience.cfm 